Article

\title{
In-Situ Vacuum Assisted Gas Stripping Recovery System for Ethanol Removal from a Column Bioreactor
}

\author{
Martina Andlar ${ }^{1}$ (D), Damir Oros ${ }^{1}$, Tonči Rezić ${ }^{1, *}$, Roland Ludwig ${ }^{2}$ and Božidar Šantek ${ }^{1}$ \\ 1 Department of Biochemical Engineering, Faculty of Food Technology and Biotechnology, \\ University of Zagreb, Pierottijeva 6, 10000 Zagreb, Croatia; mandlar@pbf.hr (M.A.); \\ doros@pbf.hr (D.O.); bsantek@pbf.hr (B.Š.) \\ 2 Department of Food Sciences and Technology, University of Natural Resources and Life Sciences, \\ 1190 Vienna, Austria; roland.ludwig@boku.ac.at \\ * Correspondence: trezic@pbf.hr; Tel.: +385-1-4605-056
}

Received: 28 September 2018; Accepted: 6 November 2018; Published: 9 November 2018

check for updates

\begin{abstract}
A three-step process consisting of biomass hydrolysis, fermentation and in-situ gas stripping by a vacuum assisted recovery system, was optimized to increase the ethanol production from sugar beet pulp. The process combines the advantages of stripping and vacuum separation and enhances the fermentation productivity through in-situ ethanol removal. Using the design of experiment and response surface methodology, the effect of major factors in the process, such as pressure, recycling ratio and solids concentration, was tested to efficiently remove ethanol after the combined hydrolysis and fermentation step. Statistical analysis indicates that a decreased pressure rate and an increased liquid phase recycling ratio enhance the productivity and the yield of the strip-vacuum fermentation process. The results also highlight further possibilities of this process to improve integrated bioethanol production processes. According to the statistical analysis, ethanol production is strongly influenced by recycling ratio and vacuum ratio. Mathematical models that were established for description of investigated processes can be used for the optimization of the ethanol production.
\end{abstract}

Keywords: ethanol removal; column bioreactor; in-situ gas stripping; vacuum

\section{Introduction}

Conventional ethanol fermentation is a typically product inhibiting process leading to low productivity and yield. This problem can be alleviated by continuous removal of ethanol from the fermentation broth. In-situ ethanol separation increases the productivity of the fermentation broth and reduces the amount of water added to the distillation feed stream. Several processes based on continuous ethanol removal during fermentation have been developed, which include: vacuum fermentation [1], flash fermentation [2], stripping fermentation [3], extraction fermentation [4] and membrane separation $[5,6]$. In the flash fermentation content of a fermenter circulates through a vacuum flash tank. The partial vaporization of water and fermentation products in the flash tank generates a vapor phase rich in solvents and vapor-depleted liquid stream. The vapor is condensed and sent to distillation section while vapor-depleted liquid stream is returned to the fermenter [7]. Stripping fermentation is a simple technique and does not require expensive equipment. Gas $\left(\mathrm{CO}_{2}, \mathrm{~N}_{2}\right)$ can be sparged through the fermenter and the volatile ethanol can recovered from the condenser [8]. Flash fermentation and stripping fermentation processes are straightforward, suitable for implementation in industrial applications and have little influence on the culture medium. However, their overall low separation efficiency and compressor restrictions limit the efficiency of these processes. Therefore, 
a new ethanol flash-strip fermentation process has been proposed, which combines the advantages of both stripping- and flash-fermentation and improves the fermentation productivity by increasing the in-situ ethanol removal [9]. In these processes, a combination of a gas with sterile air enabled the circulation of the medium to replace mechanical agitation and reduce the energy demand. A main cost factor is the compression of the stripping gas, which is injected into the bottom of the fermenter by a sparger [10].

To reduce costs, several options for gas stripping operations were developed [11]. The fermenter content can be recovered through a stripping column, where ethanol is removed by recycling the $\mathrm{CO}_{2}$ gas through a condenser [12]. With the aim to increase productivity and reduce product recovery costs [13] several different gases (air, $\mathrm{CO}_{2}, \mathrm{~N}_{2}$ ) have been studied [14]. For the ethanol production from sugarcane, a research group from Brazil tested $\mathrm{N}_{2}$ as a stripping carrier gas [15]. The stripping experiment was done in a continuous fermentation process with a residence time of 7-9 h, without recycling of the stripping gas. It was observed that stripping the reaction products (ethanol and $\mathrm{CO}_{2}$ ) increased productivity while lowering the formation of other side products of the yeast metabolism. After the stripped ethanol was recovered, the $\mathrm{CO}_{2}$ and gaseous stream was purified using water wash scrubbing. To further lower the production costs, part of the $\mathrm{N}_{2}$ can be replaced with $\mathrm{CO}_{2}$, because $\mathrm{N}_{2}$ has only $2 / 3$ of the mass of the same volume of $\mathrm{CO}_{2}$ at atmospheric pressure. These savings would be even higher as the cost of energy decreases [16].

In a study of de Vrije et al. [17] gas stripping of isopropanol, butanol and ethanol (IBE) by $\mathrm{N}_{2}$ was studied. The process of gas stripping using nitrogen gas was applied to a batch, a repeated batch and continuously grown cultures of Clostridium beijerinckii cultivated on a substrate mixture containing glucose and xylose, which mimics the sugar content of lignocellulosic biomass hydrolysates. The aim of the study was to determine the optimal conditions for a stable, high producing IBE microbial culture. The result was an innovative repeated-batch process where the gas stripping is performed at $70{ }^{\circ} \mathrm{C}$ resulting in a prolonged stable IBE culture.

To make the process more sustainable and to accomplish continuous production with high conversion efficiency, gas stripping solid state fermentation (GS-SSF) was developed. Chen et al. [18] optimized the conditions of GS-SSF for the bioethanol production from sweet sorghum stalk. When compared with conventional solid-state fermentation, the ethanol yield increased from 6 to $10 \%$ under the same conditions (stripping time, temperature, particle size) and reached $22.7 \mathrm{~g}$ EtOH per $100 \mathrm{~g}$ dry biomass. The optimized initial gas stripping time was $10 \mathrm{~h}$, while the gas stripping temperature was set to $35{ }^{\circ} \mathrm{C}$ at a total fermentation time of $28 \mathrm{~h}$. The particle size of sweet sorghum stalk was $0.15 \mathrm{~cm}$. The accomplished ethanol stripping efficiency of the process was 77.5\%. During GS-SSF, the ethanol yield increased by $30 \%$ with the particle size decreasing from $0.4 \mathrm{~cm}$ to $0.05 \mathrm{~cm}$. The gas stripping reduced the ethanol inhibition effect and improved the mass and heat transfer efficiency, which enhanced the solid-state fermentation performance.

Sonego et al. [19] investigated ethanol production by fed-batch fermentation with $\mathrm{CO}_{2}$ stripping in a 5-L bubble column bioreactor under different substrate concentrations. The experiment was modeled with a hybrid Andrews-Levenspiel model, which is able to accurately predict the behavior of conventional and extractive fed-batch ethanol fermentations. Process kinetic parameters were evaluated by modeling of conventional fed-batch fermentations without stripping using a sucrose concentration of $180 \mathrm{~g} \mathrm{~L}^{-1}$ in the feed at a temperature of $34{ }^{\circ} \mathrm{C}$ and filling times of 3 and $5 \mathrm{~h}$. By applying ethanol stripping, the inhibitory effects of the substrate and ethanol on the yeast cells were reduced, which allowed substrate concentrations in the feed of up to $240 \mathrm{~g} \mathrm{~L}^{-1}$. The total ethanol concentration was 33\% higher when using the fed-batch ethanol fermentation compared to conventional fed-batch fermentation without ethanol removal [19]. With the aim of analyzing economic possibilities of continuous ethanol production from lignocellulose at high solid loadings, a techno-economic analysis was carried out. From the obtained results it was obvious that in-situ removal of ethanol considerably improved the economic aspect of the processes [20]. The experiments reported in this study were conducted to further investigate and characterize the performance of the 
saccharification and fermentation of high sugar beet pulp (SBP) combined with gas stripping and to optimize the effect of vacuum rate, recycling ratio and solids concentration on ethanol production in a column bioreactor [21]. The aim of this work was to develop an integrated bioprocess for ethanol production and separation from selected lignocellulosic raw material (sugar beet pulp) by using column bioreactor. A novel vacuum assisted in-situ gas striping recovery system for ethanol removal from the column bioreactor was successfully implemented resulting in increased productivity and reduced product recovery costs.

\section{Materials and Methods}

\subsection{Column Bioreactor and In-Situ Gas Striping Vacuum Assisted Recovery System}

The column bioreactor is constructed as a $0.6 \mathrm{~m}$ long, double-walled Pyrex glass tube with an inner diameter of $0.025 \mathrm{~m}$, resulting in a total volume of approx. $1.2 \mathrm{~L}$. The bioreactor was vertically placed and integrated into the experimental apparatus shown in Figure 1. The figure also shows a scheme of the vacuum assisted gas stripping recovery system. In order to make the strip-flash fermentation work smoothly, a column bioreactor (3) and a recirculation-loop (holdup volume of $0.15 \mathrm{~L}$ ) was designed to overcome the problem of mixing. The flow rate was controlled by a peristaltic pump (7) and the temperature regulated via the circulation of thermostatted water through the double walls of the column reactor. The carbon dioxide used for stripping was supplied by a 200 bar $\mathrm{CO}_{2}$ bottle with reduction valves connected to a flowmeter to regulate the flow rate (6). To maintain a constant temperature of the culture medium, the $\mathrm{CO}_{2}$ was warmed up by a heater (2) prior to its application via a sparger at the bottom of the reactor (sinter glass with pore dimension 40-100 $\mu \mathrm{m}$ ). The under-pressure of the system was regulated by a vacuum pump (5) operated from 25 to $100 \mathrm{kPa}$. The product stripped by the gas was collected in a sample bottle immersed in ice-water. This was done by passing it through a condenser (4), the temperature of which was kept at $4^{\circ} \mathrm{C}$ by a chiller.

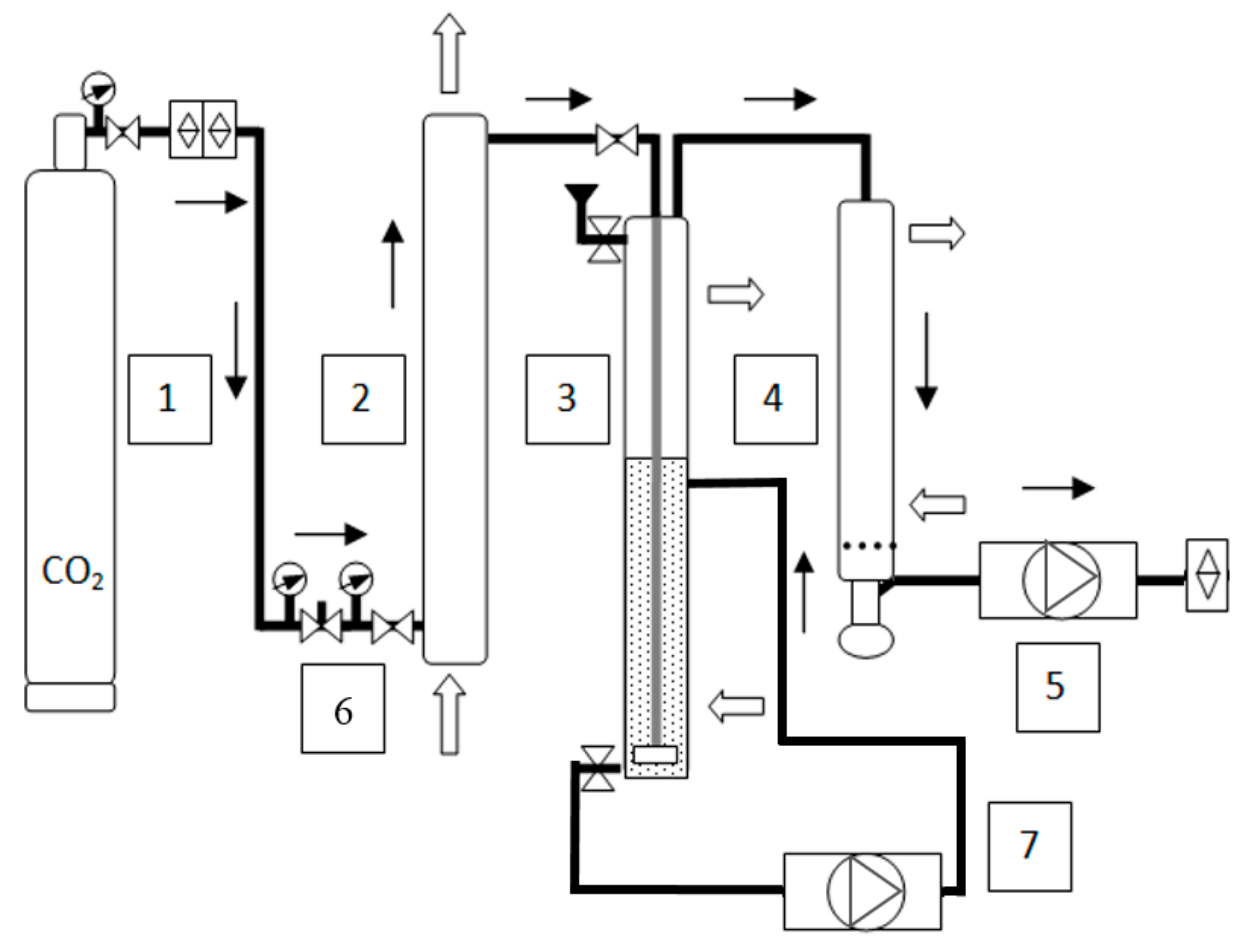

Figure 1. Schematic representation of the vacuum assisted in-situ gas stripping recovery system with the column bioreactor. $1 . \mathrm{CO}_{2}$ bottle; 2 . Gas heater; 3 . Column bioreactor; 4 . Condenser; 5 . Vacuum pump; 6. Gas rotor-flowmeter; 7. Peristaltic pump. 
In the present study, enzymatic hydrolysis and fermentation of SBP in the column bioreactor was optimized in terms of pressure, recycling ratio and solid concentration. Initially, the column bioreactor was filled with defined SBP loadings $\left(60-180 \mathrm{~g} \mathrm{~L}^{-1}\right.$ in $50 \mathrm{mM}$ citrate buffer, $\mathrm{pH} 4.5 ; 1 \mathrm{~L}$ total volume) and separately sterilized by hot steam $\left(121^{\circ} \mathrm{C}, 20 \mathrm{~min}\right)$. Hydrolysis started with addition of $14.0 \pm 0.1 \mathrm{~g} \mathrm{~L}^{-1}$ Ultrazym AFP-L, which showed the highest product release efficiency in a previous optimization experiment [22]. Additionally, the fungal secretome of Neurospora crassa grown on sugar beet pulp was added to a final concentration of $0.1 \mathrm{mg}$ protein per $\mathrm{g}$ of SBP [23]. The final reaction volume was $1 \mathrm{~L}$. The hydrolysis was performed at $\mathrm{pH} 4.5$ and $39{ }^{\circ} \mathrm{C}$. Samples were withdrawn and analyzed after $72 \mathrm{~h}$. After $72 \mathrm{~h}$ of enzymatic treatment, fermentation was started by addition of the yeast culture. The initial yeast concentration in the bioreactor was $30 \times 10^{6} \mathrm{CFU} \mathrm{mL}^{-1}$. The batch fermentation was performed at $30{ }^{\circ} \mathrm{C}$ under atmospheric pressure and at a recirculation rate of 0.5-1.5 $\mathrm{L} \mathrm{h}^{-1}$. Samples were withdrawn and analyzed after $24 \mathrm{~h}$. The gas stripping was performed $24 \mathrm{~h}$ after the start of the fermentation and was initiated by applying $20 \mathrm{~L} \mathrm{~h}^{-1} \mathrm{CO}_{2}$ through the sparger to create gas bubbles in the column bioreactor under a pressure of 25 or $50 \mathrm{kPa}$. Ethanol vapor was collected in the condenser and cooled to $4{ }^{\circ} \mathrm{C}$. The condensate was analyzed after 20 min of stripping. Sunflower oil was used as antifoam and $1 \mathrm{~mL}$ was added manually to the fermenter.

\subsection{Sugar Beet Pulp, Enzymes and Microorganisms}

Dried sugar beet pulp (SBP) with a residual moisture content of $9 \% \mathrm{w} / \mathrm{w}$ was obtained from the Sladorana d.o.o. sugar factory (Županja, Croatia) and ground to a particle size of $0.3-0.5 \mathrm{~mm}$ (Moulinex mill; type-505). SBP is mainly composed of cellulose (25-30\%), hemicelluloses (24-32\%), pectin (38-62\%) while the lignin content is typically low ( 1\%) [24]. Ultrazym AFP-L $\left(14.0 \pm 0.1 \mathrm{~g} \mathrm{~L}^{-1}\right.$, multi-enzyme complex with polygalacturonase and cellulase activities) was obtained from Novozymes (Bagsværd, Denmark) [22]. N. crassa crude extract (0.1 $\mathrm{mg}$ protein per $\mathrm{g}$ of SBP) was obtained as described previously [23]. The yeast strain utilized in this study was Saccharomyces cerevisiae Y9 (ATCC ${ }^{\circledR}$ MYA-4941) which was previously used for the fermentation of SBP hydrolysates [23]. The yeast strain was maintained on YPD medium containing per liter: $4 \mathrm{~g}$ glucose, $10 \mathrm{~g}$ peptone (casein hydrolysates) and $5 \mathrm{~g}$ yeast extract. A single isolated colony was used to inoculate a $250 \mathrm{~mL}$ flask containing $100 \mathrm{~mL}$ YPD medium. The inoculum was incubated anaerobically for 18 to $24 \mathrm{~h}$ at $30^{\circ} \mathrm{C}$ before being transferred into the column bioreactor.

\subsection{Analytical Procedures}

Concentrations of released reducing sugars were measured by the 3,5-dinitrosalicylic acid (DNSA) assay according to a previously published protocol [25]. Briefly, $600 \times 10^{-6} \mathrm{~L}$ of properly diluted sample solution was mixed with $600 \times 10^{-6} \mathrm{~L}$ of DNSA reagent containing $10 \mathrm{~g} \mathrm{~L}^{-1} \mathrm{DNSA}, 0.5 \mathrm{~g} \mathrm{~L}^{-1}$ sodium sulfite, $10 \mathrm{~g} \mathrm{~L}^{-1}$ sodium hydroxide and $2 \mathrm{~g} \mathrm{~L}^{-1}$ phenol. The mixture was incubated for $15 \mathrm{~min}$ at $95{ }^{\circ} \mathrm{C}$ to induce color formation, which was stopped by adding $200 \times 10^{-6} \mathrm{~L}^{-1}$ of a $40 \mathrm{~g} \mathrm{~L}^{-1}$ ice-cold potassium sodium tartrate solution. Absorbance was immediately read at $575 \mathrm{~nm}$ and compared to a calibration curve generated with glucose. Carbohydrates released after enzymatic SBP hydrolysis and fermentation in the column bioreactor were quantified by HPLC on a Supelcogel C-610H column using a refractive index detector (RID, Shimadzu 10 A VP; Kyoto, Japan). Analytes were separated at a flow rate of $0.5 \mathrm{~mL} \mathrm{~min}^{-1}$ with $0.1 \% \mathrm{H}_{3} \mathrm{PO}_{4}$ as eluent at a constant temperature of $30^{\circ} \mathrm{C}$. Before analysis, all samples were mixed with $\mathrm{ZnSO}_{4}$ to a final concentration of $10 \%$ to induce protein precipitation. Solid debris was removed by centrifugation $\left(4500 \mathrm{~min}^{-1}\right.$ for $20 \mathrm{~min}$ ). Before column application, sample solutions were passed through a $0.20 \mu \mathrm{m}$ filter.

\subsection{Statistical Analysis}

The experimental domain (including minimal and maximal values of independent variables and factors) was designed on the basis of preliminary research [24]. The experimental research plan was based on a fractional factorial design. Three levels design is used for the study of linear and quadratic 
term effects of three factors (pressure, recycling ratio and SBP concentration) where each on three levels (hydrolysis, fermentation and vacuum assisted gas stripping recovery step) was investigated separately. SBP concentration levels were 60,120 and $180 \mathrm{~g} \mathrm{~L}^{-1}$, the recycling ratios $0.5,1.0$ and $1.5 \mathrm{~L} \mathrm{~h}^{-1}$ and pressure rates 25,50 and $100 \mathrm{kPa}$. The influence of the factors was investigated using the data analysis software Statistica version 10 (StatSoft, Palo Alto, CA, USA). Three-dimensional surface plots were generated for the results of hydrolysis, fermentation and vacuum assisted gas stripping steps. The interaction of the investigated factors (pressure rate, recycling ratio and SBP concentration) on the production of sugars and ethanol were analyzed using Pareto charts. Statistical significance was assessed at $p<0.05$ for all factors. Moreover, mathematical models for the description of responsive variables (ethanol and sugar concentrations) with the investigated factors were established.

\section{Results and Discussion}

\subsection{Evaluation of the Vacuum Assisted Gas Stripping for Ethanol Removal after SBP Hydrolysis and Fermentation}

Stripping with $\mathrm{CO}_{2}$ was tested on enzymatically pre-treated and fermented sugar beet pulp (SBP) at atmospheric and below-atmospheric pressures in a column bioreactor. The response surface methodology (RSM) was applied to the output data to evaluate the impact of process variables (investigated factors) on the efficiency of the in-situ gas stripping vacuum assisted system for ethanol removal. The results of the RSM approach were correlations between response variables (sugar or ethanol concentrations) and the investigated factors (pressure, recycling rate and solids concentration). The process was conducted as a three-step process including the (i) enzyme hydrolysis as the initial step; (ii) yeast fermentation and ethanol production as the second step and (iii) in-situ gas stripping, vacuum distillation and ethanol removal as the third step. All stages of the process were done sequentially in the column bioreactor system described in the Section 2.1.

Response surface model plots for the concentrations of released sugars as a function of recycling ratio $\left(0.5,1\right.$ and $\left.1.5 \mathrm{~L} \mathrm{~h}^{-1}\right)$ and solid concentration $\left(60,120\right.$ and $\left.180 \mathrm{~g} \mathrm{~L}^{-1}\right)$ were fitted to obtain response variables for the hydrolysis step (Figure 1). Generally, the quantities of carbohydrates released in the hydrolysis step are considerably higher than in any previous tested system [21-23]. During the previous investigation of SBP hydrolysis, Ultrazym AFP-L was selected as the most efficient enzyme mixture and optimal conditions for the hydrolysis were investigated [21]. Optimal $\mathrm{pH}$ of 4.5, temperature of $39^{\circ} \mathrm{C}$ and enzyme loadings (Ultrazym AFP-L $\left(14.0 \pm 0.1 \mathrm{~g} \mathrm{~L}^{-1}\right)$ and fungal secretome of Neurospora crassa ( $0.1 \mathrm{mg}$ protein per g of SBP)) were used to provide an efficient hydrolysis in the tested column bioreactor system. Ultrazym AFP-L was further supplemented with crude extract from the cellulose-degrading fungus $N$. crassa, which secretes the redox enzymes cellobiose dehydrogenase and several lytic polysaccharide monooxygenases when grown on cellulosic substrates [26,27]. These enzymes were previously recognized to de-crystallize cellulose, which boosts the performance of hydrolytic enzymes commonly used in biorefineries [28].

In the presented research, the hydrolysis efficiency of SBP was tested in a column bioreactor to obtain optimum performances. Optimum performances, indicated by the total concentration of hydrolyzed sugars, were measured at high recycling ratios and SBP concentrations, and large global optima were observed (Figure 2).

A correlation between the recycling ratio and the solid (SBP) concentration for the fermentation step was found based on the experimental data shown in Figure 3. Compared to the results of the hydrolysis (Figure 2), large global optima were observed with an additional shift to higher values of the tested factors (recycling ratio and SBP concentration; Figure 3b). A shift to higher concentrations of solid particles can be explained by the step-wise processes and may be a consequence of the efficient hydrolysis in the first step. However, absolute values were lower because of the reduction of the solid concentration after hydrolysis. Previous investigations showed that an efficient hydrolysis directly affects the fermentation step, which highlights the necessity to optimize the hydrolysis step [21]. Both results indicate that the hydrolysis and fermentation steps can be successfully conducted in the 
tested column bioreactor system employing high solid loadings. Adaptation and optimization of the recycling ratio was an important factor in the bioreactor performance. Efficient mixing in the solid and semi-solid bioreactor system is one of the main obstacles for efficient hydrolysis/fermentation, and many authors have addressed this issue $[18,19,23]$. In our column bioreactor, we identified the recycling step as the most efficient parameter. Variations thereof were also tested, such as the stripping with air during the hydrolysis step, but the efficiency of mixing was unsatisfying (indicated by precipitation of a high number of solid particles under the sparger). If an efficient hydrolysis step is done, fermentation and separation are improved by successful liquefaction and the reduction in the concentration of solid particles. The solid particle reduction was in the range of 30.5 to $56.3 \%$ after the hydrolysis step. An increment in hydrolyzed sugar concentration $\mathrm{c}_{\mathrm{G}}$ had an overall positive effect on the ethanol production (see Figure $3 \mathrm{a}, \mathrm{c}$ ). The measured carbohydrate concentration was in the range from $20.98 \mathrm{~g} \mathrm{~L}^{-1}$ to $50.77 \mathrm{~g} \mathrm{~L}^{-1}$. Consequently, the concentration of ethanol during the fermentation step was in the range of 5.3 to $18.2 \mathrm{~g} \mathrm{~L}^{-1}$, with the efficiency ranging from 50 to $97 \%$ according the theoretical yield. For comparison, Taylor et al. [16] using an average glucose concentration in the fermenter of $9 \mathrm{~g} \mathrm{~L}^{-1}$, were producing $88 \%$ of the maximum theoretically yield of ethanol.

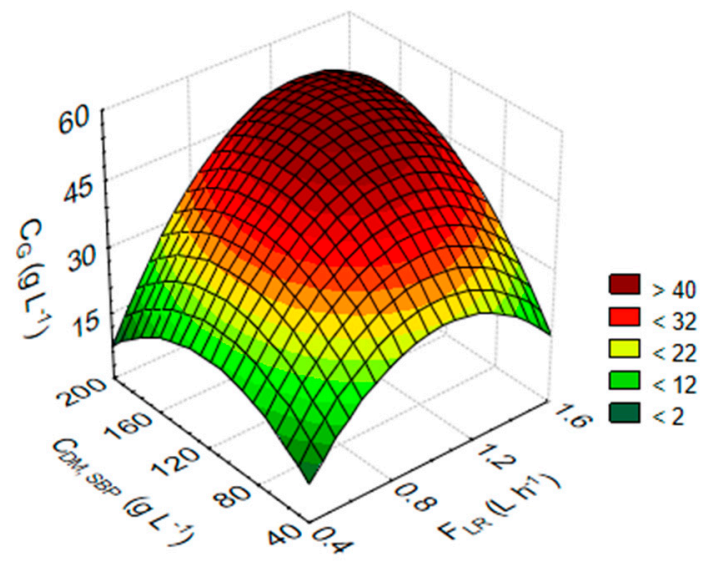

Figure 2. Changes in sugar concentrations in the hydrolysis step with investigated factors (recycling ratio and solid concentration).

As the three-step process fermentation followed the hydrolysis, the overall efficiency strongly depends on the hydrolysis. As mentioned before, a lower efficiency was observed in experiments employing a low recycling ratio $\left(0.5 \mathrm{~L} \mathrm{~h}^{-1}\right)$, in which insufficient mixing reduced the yields after the hydrolysis and fermentation step.

In the presented study ethanol separation from the fermentation broth was conducted in the third step by an in-situ vacuum-stripping process. $\mathrm{CO}_{2}$ was selected as carrier gas at a flow rate of $20 \mathrm{~L} \mathrm{~h}^{-1}$. Higher $\mathrm{CO}_{2}$ flow rates decrease the temperature in the column bioreactor (data not shown) [24]. A pressure of $25 \mathrm{kPa}$ was selected as the minimum under-pressure as a result of the equipment limitations. The in-situ gas stripping vacuum system was additionally evaluated at different pressures $(25,50$ and $100 \mathrm{kPa})$ based on the concentration of ethanol collected as condensate in the cooled column. The effect of pressure on the in situ vacuum-stripping is presented in Figures 4 and 4 . The plane shape of the diagram indicates an important influence of the pressure on the separation efficiency. For the lower pressure, higher changes in the ethanol concentration in the condensate were measured with an additional positive effect on the separation efficiency. A plot of the ethanol concentrations in the condensate as a function of the SBP loading and ethanol (produced by fermentation) for the vacuum-stripping step is shown in Figure $4 \mathrm{~b}$. High solid loadings $\left(<120 \mathrm{~g} \mathrm{~L}^{-1}\right)$ and high recycling ratios $\left(<1 \mathrm{~L} \mathrm{~h}^{-1}\right)$ improved ethanol production in the fermentation step. Consequently, a similar trend was observed in the vacuum-stripping step for solid loadings, which is the result of the higher ethanol production observed in these ranges (Figures 3 and 4). 


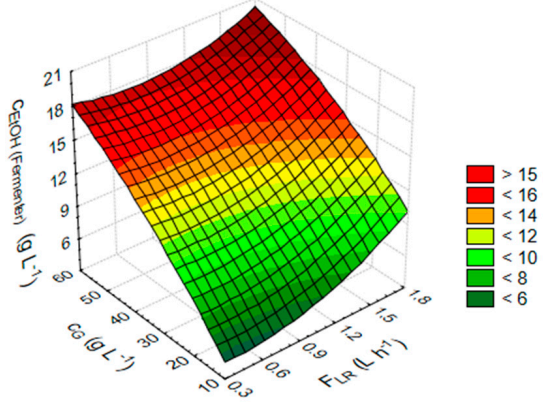

(a)

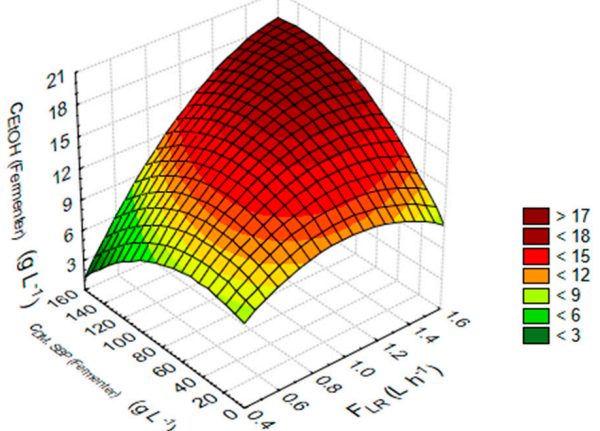

(b)

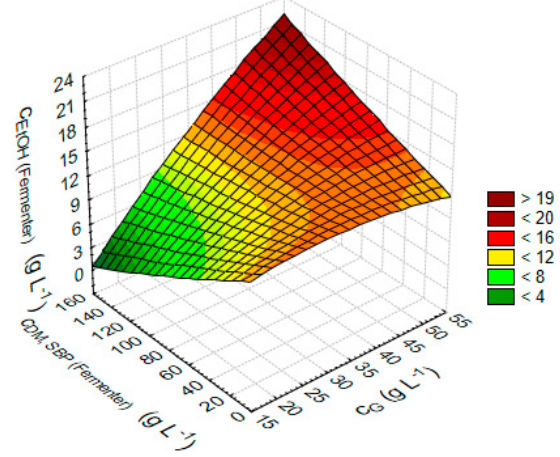

(c)

Figure 3. Changes of ethanol concentration in the fermentation step with investigated factors (recycling ratio, solid and carbohydrates concentration) $(\mathbf{a}-\mathbf{c})$.

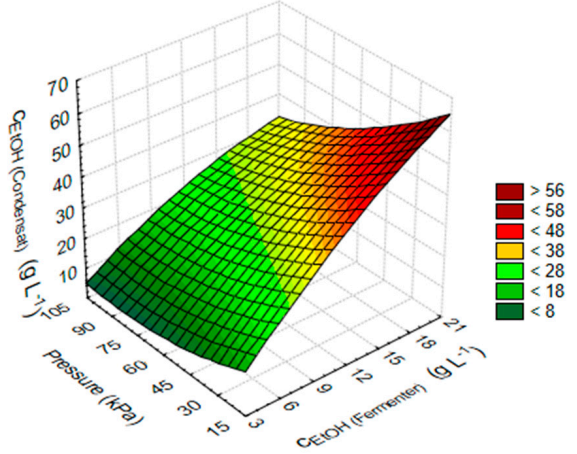

(a)

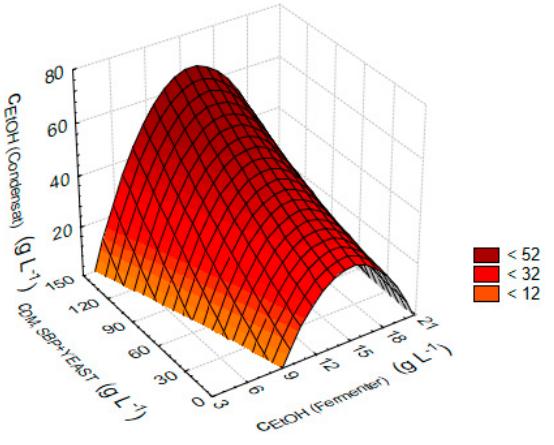

(b)

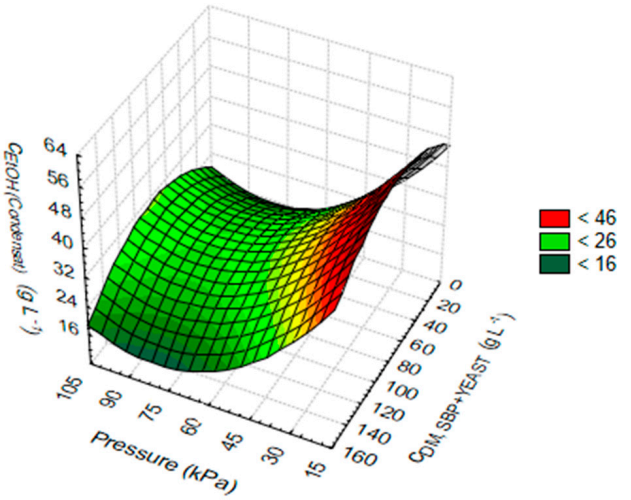

(c)

Figure 4. Changes of ethanol concentration in the vacuum assisted gas stripping recovery step with investigated factors (vacuum rate, solid and ethanol concentration) (a-c). 
Mathematical models describing the response variations (sugars and ethanol concentrations) as a function of variances in the three-step hydrolysis, fermentation and in-situ gas stripping vacuum assisted process of ethanol production from sugar beet pulp are shown in Table 1. All mathematical models describing the responses variations presented quadratic terms (Figures 2-4). To obtain a deeper understanding of the process, we performed in-depth statistical analyses of the obtained data and optimized the model for the vacuum assisted gas stripping recovery system for ethanol removal.

Table 1. Polynomial equations fitted to the results of the three-step hydrolysis, fermentation and in-situ gas stripping vacuum assisted process of ethanol production from sugar beet pulp.

\begin{tabular}{|c|c|}
\hline Response & Model Equation \\
\hline \multirow[t]{2}{*}{$\mathrm{c}_{\mathrm{G}}\left(\mathrm{g} \mathrm{L}^{-1}\right)$ against $\mathrm{F}_{\mathrm{LR}}\left(\mathrm{L} \mathrm{h}^{-1}\right)$ and $\mathrm{c}_{\mathrm{DM}, \mathrm{SBP}}$ (Hydrolysis) $\left(\mathrm{g} \mathrm{L}^{-1}\right)$} & $\begin{array}{l}\mathrm{c}_{\mathrm{G}}\left(\mathrm{g} \mathrm{L}^{-1}\right)=-37.0244+95.9033 \times x+0.3898 \times y-48.7733 \\
\times x \times x+0.1716 \times x \times y-0.0019 \times y \times y\end{array}$ \\
\hline & Fermentation step \\
\hline$c_{\text {EtOH (Fermenter) }}\left(\mathrm{g} \mathrm{L}^{-1}\right)$ against $\mathrm{F}_{\mathrm{LR}}\left(\mathrm{L} \mathrm{h}^{-1}\right)$ and $\mathrm{c}_{\mathrm{G}}\left(\mathrm{g} \mathrm{L}^{-1}\right)$ & $\begin{array}{l}\mathrm{c}_{\mathrm{EtOH}}(\mathrm{Fermenter})\left(\mathrm{g} \mathrm{L}^{-1}\right)=1.0341-1.6724 \times x+0.4049 \times y \\
+2.7967 \times x \times x-0.0466 \times x \times y-0.0017 \times y \times y\end{array}$ \\
\hline $\begin{array}{l}c_{\text {EtOH (Fermenter) }}\left(\mathrm{g} \mathrm{L}^{-1}\right) \text { against } \mathrm{F}_{\mathrm{LR}}\left(\mathrm{L} \mathrm{h}^{-1}\right) \text { and } \\
\mathrm{c}_{\mathrm{DM}, \mathrm{SBP} \text { (Fermenter) }}\left(\mathrm{g} \mathrm{L}^{-1}\right)\end{array}$ & $\begin{array}{l}\mathrm{c}_{\text {EtOH }}(\text { Fermenter })\left(\mathrm{g} \mathrm{L}^{-1}\right)=2.095+18.942 \times x+0.0064 \times y- \\
9.4392 \times x \times x+0.0899 \times x \times y-0.0005 \times y \times y\end{array}$ \\
\hline $\begin{array}{l}c_{E t O H} \text { (Fermenter) }\left(\mathrm{g} \mathrm{L}^{-1}\right) \text { against } \mathrm{c}_{\mathrm{G}}\left(\mathrm{g} \mathrm{L}^{-1}\right) \text { and } \\
\mathrm{c}_{\mathrm{DM}, \mathrm{SBP}} \text { (Fermenter) }\left(\mathrm{g} \mathrm{L}^{-1}\right)\end{array}$ & $\begin{array}{l}\mathrm{c}_{\mathrm{EtOH}} \text { (Fermenter) }\left(\mathrm{g} \mathrm{L}^{-1}\right)=10.7033+0.1937 \times x-0.1385 \times \\
y 0.0032 \times x \times x+0.0035 \times x \times y+4.7931 \times 10^{-5} \times y \times y\end{array}$ \\
\hline $\begin{array}{l}\mathrm{c}_{\mathrm{EtOH}}\left(\text { Condensate) }\left(\mathrm{g} \mathrm{L}^{-1}\right) \text { against } \mathrm{c}_{\mathrm{EtOH}} \text { (Fermenter) }\left(\mathrm{g} \mathrm{L}^{-1}\right) \text { and }\right. \\
\mathrm{c}_{\mathrm{DM}}, \mathrm{SBP}+\mathrm{y} \text { Yeast }\left(\mathrm{g} \mathrm{L}^{-1}\right)\end{array}$ & $\begin{array}{l}\mathrm{C}_{\mathrm{EtOH}}(\text { Condensate) } \\
\left.\times \mathrm{g} \mathrm{L}^{-1}\right)=-156.5581+24.9372 \times x+0.4586 \\
\times y-0.8373 \times x \times x-0.021 \times x \times y+0.0006 \times y \times y\end{array}$ \\
\hline $\begin{array}{l}\mathrm{c}_{\mathrm{EtOH}}(\text { Condensate })\left(\mathrm{g} \mathrm{L}^{-1}\right) \text { against Pressure }(\mathrm{kPa}) \text { and } \\
\mathrm{c}_{\mathrm{DM}}, \mathrm{SBP}+\text { Yeast }\left(\mathrm{g} \mathrm{L}^{-1}\right)\end{array}$ & $\begin{array}{l}\mathrm{C}_{\mathrm{EtOH}}(\text { Condensate })\left(\mathrm{g} \mathrm{L}^{-1}\right)=61.9621-0.1165 \times x+0.2763 \times \\
y+7.2934 \times 10^{-5} \times x \times x-4.8328 \times 10^{-6} \times x \times y- \\
0.0017 \times y \times y\end{array}$ \\
\hline
\end{tabular}

\subsection{Statistical Analysis and Optimisation of Integrate Ethanol Production Process}

In order to visualize the function of three variables-factors (recycling ratio, solid concentration and pressure) from the three-dimensional data presented in Figures 2-4 contour plots from these graphs were created (Figure 5).

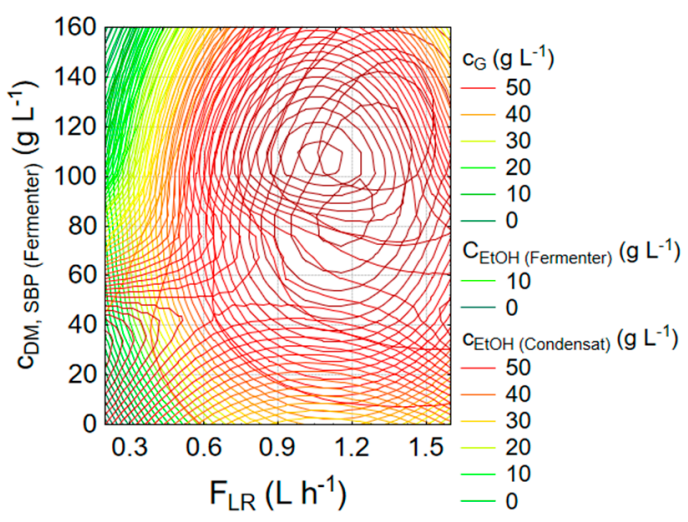

(a)

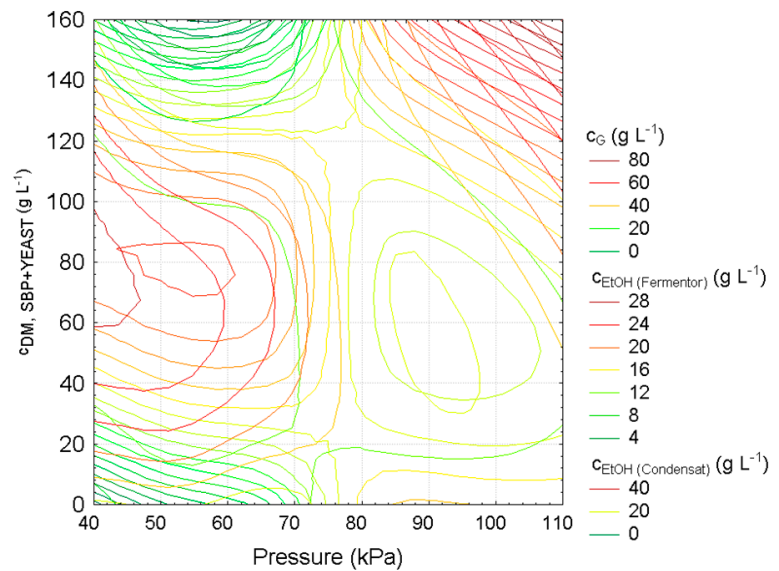

(b)

Figure 5. Contour plots of sugar- and ethanol concentrations during hydrolysis, fermentation and vacuum stripping as a function of (a) recycling ratio and solid concentration; (b) pressure and solid concentration. 
This contour plot shows the level curves from two of the three-dimensional graphs as a function of recycling ratio, solid concentration and pressure. To establish such a plot, the matrix that holds the values of the function was created and the contour plot of that matrix generated. The plot of the function of the three responsive variables is shown in Figure 5 (for recycling rate and solid SBP concentration Figure 5a; and Figure 4 b for solid SBP concentration and pressure). As the indication of the optimum factor ranges for the integrated process, overlapping of the convergence areas is observed in Figure 5a.

Corresponding ethanol yields obtained after in-situ vacuum assisted gas stripping recovery system are presented in Table 2 . The ethanol yield depends on a pressure but also on a concentration of ethanol in a fermenter and condensate. The highest ethanol yield obtained was $31.50 \%$ at $25 \mathrm{kPa}$ with a measured mass of ethanol in fermenter and condensate of $17.30 \mathrm{~g}$ and $5.45 \mathrm{~g}$, respectively. The lowest ethanol yield of $5.66 \%$ was obtained at $100 \mathrm{kPa}$ under which we measured the highest mass of ethanol in a fermenter. Lower the pressure higher the ethanol yield was observed.

Table 2. Ethanol yields (\%) obtained after in-situ vacuum assisted gas stripping.

\begin{tabular}{cccc}
\hline Pressure $\mathbf{( k P a )}$ & mEtOH (Fermenter) $(\mathbf{g})$ & mEtOH (Condensate) $(\mathbf{g})$ & \% EtOH \\
\hline 25 & 10.96 & 2.94 & 26.82 \\
100 & 10.21 & 0.96 & 9.40 \\
50 & 5.30 & 1.82 & 34.34 \\
100 & 12.47 & 0.75 & 6.01 \\
50 & 14.52 & 1.94 & 13.36 \\
25 & 17.30 & 5.45 & 31.50 \\
50 & 13.70 & 1.53 & 11.17 \\
25 & 15.60 & 3.01 & 19.29 \\
100 & 18.20 & 1.03 & 5.66 \\
\hline
\end{tabular}

Using function analyses, the optimal ranges of the investigated factors (pressure rate, recycling ratio and solid concentration) for each of the studied stages were determined (Table 3). Table 3 represents optimal parameters (factors) of the in-situ gas stripping vacuum assisted recovery system for ethanol removal from the column bioreactor. Calculated optimum values of the selected factors (pressure rate, recycling ratio and solid concentration) were different for the hydrolysis and fermentation process stages as well as for the in-situ vacuum stripping processes. Optimal hydrolysis was achieved at a recycling ratio of $1.26 \mathrm{~L} \mathrm{~h}^{-1}$ and employing an SBP concentration of $156 \mathrm{~g} \mathrm{~L}^{-1}$. However, optimal values calculated for the fermentation stages were $1.45 \mathrm{~L} \mathrm{~h}^{-1}$ for the recycling ratio at an SBP concentration of $149 \mathrm{~g} \mathrm{~L}^{-1}$.

Table 3. Optimal and critical values for parameters (factors) tested in gas striping vacuum assisted recovery system for ethanol removal from the column bioreactor.

\begin{tabular}{|c|c|c|c|}
\hline Factors & Hydrolysis & Fermentation & Vacuum-Striping \\
\hline $\mathrm{F}_{\mathrm{LR}}\left(\mathrm{L} \mathrm{h}^{-1}\right)$ & 1.25 & 1.45 & - \\
\hline $\mathrm{C}_{\mathrm{DM}, \mathrm{SBP}}\left(\mathrm{g} \mathrm{L}^{-1}\right)$ & 156 & 149 & 191 (out of range) \\
\hline $\mathrm{c}_{\mathrm{G}}\left(\mathrm{g} \mathrm{L}^{-1}\right)$ & 50.61 & 75.4 (out of the range) & - \\
\hline $\mathrm{c}_{\mathrm{EtOH}}$ (Fermenter) $\left(\mathrm{g} \mathrm{L}^{-1}\right)$ & - & 13.2 & 15.5 \\
\hline $\mathrm{c}_{\mathrm{EtOH}}$ (Condensate) $\left(\mathrm{g} \mathrm{L}^{-1}\right)$ & & & 62 \\
\hline Pressure $(\mathrm{kPa})$ & - & - & $<20$ (out of range) \\
\hline
\end{tabular}

Observed results indicate differences in relation to the mixing (recycling) regime and the rheology of the SBP-slurry in the tested bioreactor system. The increase in viscosity over time is a result of the release of polymeric components during the hydrolysis, which consequently cause an increase in the optimum value of the recycling rate during the fermentative step [23]. Higher recycling rates, effective mixing and an active yeast culture used during the fermentation step ensure optimal conditions. 
Optimization results gave a sugar concentration of $75.4 \mathrm{~g} \mathrm{~L}^{-1}$ after hydrolysis. The maximal sugar concentration in our experimental approach was $50.61 \mathrm{~g} \mathrm{~L}^{-1}$ owing to the technical limitations of our column bioreactor in terms of the maximum SBP (solid) loading than can be reliably stirred. Further experimental studies on this issue are needed in order to evaluate the full potential of our computational approach. The subsequent fermentation step was conducted successfully with a maximum ethanol concentration of $18.2 \mathrm{~g} \mathrm{~L}^{-1}$. The maximal ethanol concentration calculated for the vacuum stripping was in good agreement with the average values of the ethanol concentration measured during the fermentation step (average value $13.2 \mathrm{~g} \mathrm{~L}^{-1}$ for fermentation, and optimum at $15.5 \mathrm{~g} \mathrm{~L}^{-1}$ for vacuum stripping step in the fermenter as well as $62 \mathrm{~g} \mathrm{~L}^{-1}$ in the condensate). These results indicate the possibility to further enhance the gas stripping vacuum assisted recovery system using simultaneous fermentation and vacuum assisted in-situ gas stripping ethanol recovery processes. On the contrary, the optimized SBP concentration obtained from our computational approach was beyond the investigation ranges $\left(191 \mathrm{~g} \mathrm{~L}^{-1}\right)$. Also, the pressure could not be adjusted to values below $20 \mathrm{kPa}$ with the herein employed setup. Previous investigations of similar processes arrived at comparable conclusions regarding the process parameter optimization [20]. A major advantage of such simultaneous processes is the reduction of operational costs, but the overall process efficiency is reduced as a consequence of the complexity of the process setup, which requires fine-tuning of many process parameters which are simultaneously conducted in one step. Additional statistical analyses of different stages investigated through this research are presented in Figure 6.

To verify the effects of each operational variable in the responses, Pareto charts were generated (Figure 6). In Figure 6, bars extending to the vertical line correspond to the effects of a 95\% confidence level. As can be seen from the figure, the recycling ratio and the pressure exerted a significance level of $p<0.05$. For the hydrolysis step, the recycling rate was a significant parameter with the highest $p$ value (Figure 6a Pareto chart). The concentration of SBP was insignificant for the hydrolysis as well as for the fermentation step. According to the adaptation of mixing (recycling) regime to the solid concentration, this observation indicates column bioreactor efficiency in the semi-solid process application. If mixing significantly influence process then process could be optimized by this parameter changes. On the other hand, un-significant of the SBP concentration indicate ability to conduct efficient process in the column bioreactor with high solid concentration by adaptation of mixing and recycling regime. According to the Pareto charts (Figure 6a,c), recycling rates and pressure showed to be the most significant factors for the analyzed three step processes, although with the different effects. An increase in the recycling rate had a positive effect on the hydrolysis, while decreases in vacuum (pressure) enhanced the ethanol recovery. Table 4 summarizes the literature reports on lignocellulosic biomass fermentation for bioethanol production and compares pretreatment and fermentation conditions, as well as theoretical and corresponding ethanol yields. 


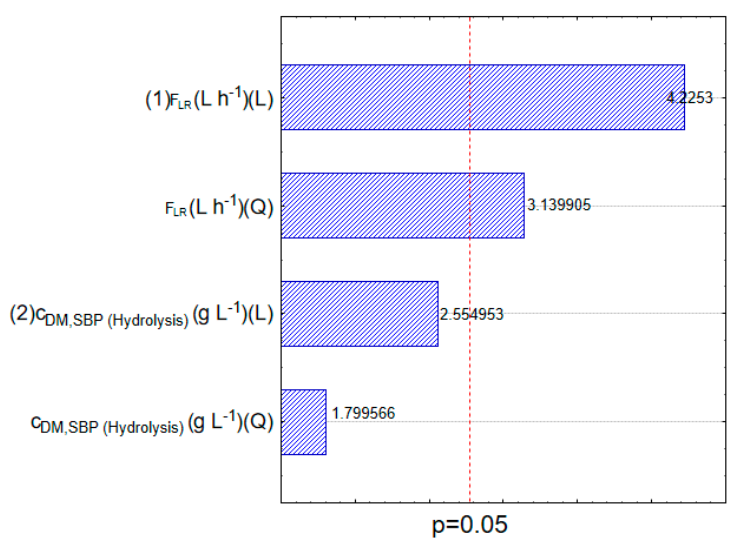

(a)

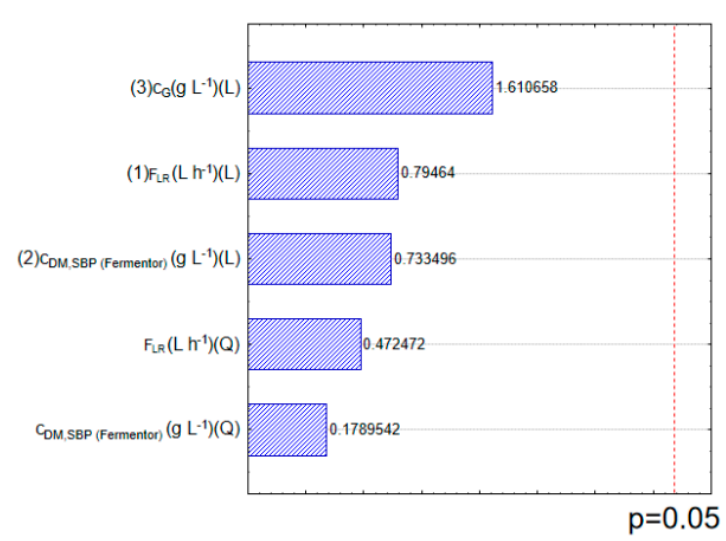

(b)

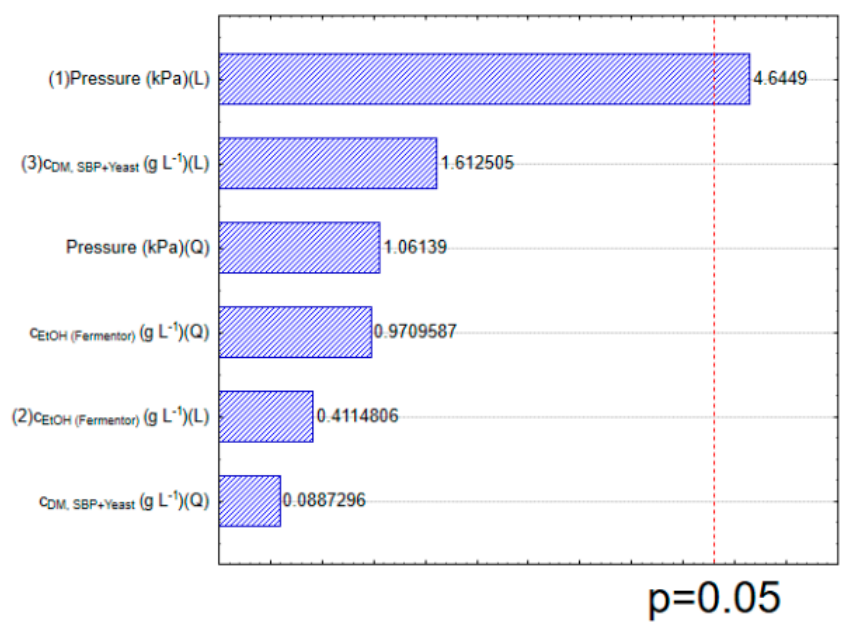

(c)

Figure 6. Pareto charts for the effects of the vacuum ratio, recycling ratio and sugar beet pulp (SBP) concentration in the: hydrolysis step (a); fermentation step (b) and vacuum stripping step (c). 
Table 4. Overview of literature reports on lignocellulosic biomass fermentation for bioethanol production.

\begin{tabular}{|c|c|c|c|c|c|c|}
\hline Feedstock & Pretreatment Conditions & Fermentation Conditions & Strain & $\begin{array}{l}\text { Theoretical Ethanol } \\
\text { Yield (\%) }\end{array}$ & $\begin{array}{l}\text { Corresponding Ethanol } \\
\text { Yield }\left(\mathrm{g} \mathrm{L}^{-1}\right)\end{array}$ & Literature \\
\hline Sugar beet pulp & $\begin{array}{l}\text { Enzyme pretreatment with Ultrazym } \\
\text { AFP-L }\left(14.0 \pm 0.1 \mathrm{~g} \mathrm{dm}^{-3}\right) \text { and } \\
\text { Neurospora crassa crude extract }(0.1 \mathrm{mg} \\
\text { protein per } \mathrm{g} \text { of SBP })\end{array}$ & $\begin{array}{l}\text { Semi-solid fermentation in a column bioreactor } \\
\text { at } 30^{\circ} \mathrm{C} \text { and } \mathrm{pH} 4.5 \text { for } 24 \mathrm{~h}\end{array}$ & $\begin{array}{l}\text { Saccharomyces cerevisiae Y9 } \\
\text { (ATCC }{ }^{\circledR} \text { MYA-4941 }\end{array}$ & 97 & 62 & this study \\
\hline Miscanthus & $\begin{array}{l}1.5 \mathrm{M} \mathrm{NaOH} \text { with stirring at } 120 \mathrm{rpm} \\
\text { and heated to } 150^{\circ} \mathrm{C} \text { for } 30 \mathrm{~min}\end{array}$ & $\begin{array}{l}\text { Liquid-state saccharification and fermentation at } \\
42^{\circ} \mathrm{C} \text { with shaking at } 150 \mathrm{rpm}\end{array}$ & Saccharomyces cerevisiae 7928 & 86.30 & 29.50 & [29] \\
\hline Sugarcane bagasse & $\begin{array}{l}\text { Acid hydrolysis of sugarcane bagasse in } \\
\text { two stages }\end{array}$ & $\begin{array}{l}\text { Continuous fermentation with cell recycle } \\
\text { system at a temperature of } 50^{\circ} \mathrm{C} \text { and a pH of } 5.0\end{array}$ & $\begin{array}{l}\text { thermotolerant yeast } \\
\text { Kluyveromyces sp. IIPE453 }\end{array}$ & 96 & 56.30 & [30] \\
\hline Rapeseed straw & $\begin{array}{l}\text { Liquid hot water pretreatment at } 217^{\circ} \mathrm{C} \\
\text { for } 42 \mathrm{~min}\end{array}$ & $\begin{array}{l}\text { Liquid-state simultaneous saccharification and } \\
\text { fermentation in an orbital shaker at } 150 \mathrm{rpm}\end{array}$ & $\begin{array}{l}\text { Saccharomyces cerevisiae, } \\
\text { enzymes: Celluclast (NS50013) } \\
\text { cellulases from Trichoderma reesei } \\
\text { and } \beta \text {-glucosidase (NS50010) } \\
\text { from Aspergillus niger }\end{array}$ & 66.60 & 17.20 & [31] \\
\hline Sweet sorghum stalk & Sterilization at $121^{\circ} \mathrm{C}$ for $15 \mathrm{~min}$ & $\begin{array}{l}\text { Traditional static solid-state fermentation } \\
\text { (TS-SSF) and gas stripping solid state } \\
\text { fermentation (GS-SSF) }\end{array}$ & Saccharomyces cerevisiae & 77.5 & 27 & [18] \\
\hline Coconut fibre & $\begin{array}{l}\text { Sequential alkaline hydrogen peroxide } \\
\left(\text { Alk- } \mathrm{H}_{2} \mathrm{O}_{2}\right) \text {-sodium hydroxide }(\mathrm{NaOH})\end{array}$ & $\begin{array}{l}\text { Semi-simultaneous saccharification and } \\
\text { fermentation at } 30^{\circ} \mathrm{C} \text { for } 40 \mathrm{~h}\end{array}$ & $\begin{array}{l}\text { Saccharomyces cerevisiae, Pichia } \\
\text { stipites and Zymomonas mobilis }\end{array}$ & 89.15 & 9.32 & [32] \\
\hline Rice straw & $\begin{array}{l}\text { Dilute acid pretreatment, then } \\
\text { delignification with } 0.5 \% \mathrm{NaOH} \text { at } 121 \\
{ }^{\circ} \mathrm{C} \text { for } 30 \mathrm{~min}\end{array}$ & $\begin{array}{l}\text { Simultaneous saccharification and fermentation } \\
\text { with agitation at } 120 \mathrm{rpm} \text { for } 72 \mathrm{~h} \text { at } 42^{\circ} \mathrm{C}\end{array}$ & Kluyveromyces sp. & 84.60 & 24.63 & [33] \\
\hline Hinoki cypress & $\begin{array}{l}\text { Steam treatment }\left(150{ }^{\circ} \mathrm{C} \text { for } 2 \mathrm{~h}\right) \text { with } \\
\text { wet disk milling }\end{array}$ & $\begin{array}{l}\text { Yeast-based simultaneous saccharification and } \\
\text { fermentation at } 58^{\circ} \mathrm{C} \text { with shaking at } 125 \mathrm{rpm}\end{array}$ & $\begin{array}{l}\text { S. cerevisiae D5A (ATCC 200062), } \\
\text { C. thermocellum (ATCC27405) }\end{array}$ & 63.40 & - & [34] \\
\hline Sugar cane molasses & $\begin{array}{l}\text { Sterilization at } 121^{\circ} \mathrm{C} \text { and } 15 \mathrm{psig} \text { for } \\
30 \mathrm{~min}\end{array}$ & $\begin{array}{l}\text { Extractive batch fermentation using } \mathrm{CO}_{2} \text { as a } \\
\text { stripping gas }\end{array}$ & $\begin{array}{l}\text { commercial lyophilized } \\
\text { Saccharomyces cerevisiae }\end{array}$ & $\begin{array}{l}25 \% \text { higher } \\
\text { compared with to the } \\
\text { conventional } \\
\text { fermentation }\end{array}$ & 43.30 & [35] \\
\hline Paper bark tree & Subcritical water at $180^{\circ} \mathrm{C}$ for $30 \mathrm{~min}$ & $\begin{array}{l}\text { Anaerobic condition in an orbital shaker } \\
\left(150 \mathrm{rpm}, 37^{\circ} \mathrm{C}\right) \text { for } 120 \mathrm{~h}\end{array}$ & $\begin{array}{l}\text { Ethanol Red }{ }^{\circledR} \text { Saccharomyces } \\
\text { cerevisiae }\end{array}$ & 91 & 24.70 & [36] \\
\hline $\begin{array}{l}\text { Fermentation } \\
\text { P2 medium }\end{array}$ & $\begin{array}{l}\text { Sterilization at } 121^{\circ} \mathrm{C} \text { and } 15 \mathrm{psig} \text { for } \\
30 \mathrm{~min}\end{array}$ & $\begin{array}{l}\text { Integrated fermentation system with } \\
\text { intermittent gas stripping }\left(\mathrm{CO}_{2} \text { and } \mathrm{H}_{2}\right) \text { at } 37^{\circ} \mathrm{C} \\
\text { and pH 5.0 }\end{array}$ & $\begin{array}{l}\text { Clostridium acetobutylicum JB200 } \\
\text { (ATCC 55025) }\end{array}$ & 2 & 9.66 & [37] \\
\hline Olive tree pruning & $\begin{array}{l}\text { Liquid hot water pretreated at } 210^{\circ} \mathrm{C} \\
\text { with magnetic agitation }\end{array}$ & $\begin{array}{l}\text { Liquid-state simultaneous saccharification and } \\
\text { fermentation at } 35^{\circ} \mathrm{C} \text { for } 72 \mathrm{~h} \text { and } 150 \mathrm{rpm}\end{array}$ & Saccharomyces cerevisiae & 50 & 31.10 & [38] \\
\hline Corn stover & Steam explosion at $200^{\circ} \mathrm{C}$ for $4 \mathrm{~min}$ & $\begin{array}{l}\text { Semi-continuous liquid-state simultaneous } \\
\text { saccharification and fermentation }\left(37^{\circ} \mathrm{C} \text { for }\right. \\
60 \mathrm{~h})\end{array}$ & $\begin{array}{l}\text { yeast mutant strain } \\
\text { Saccharomyces cerevisiae } \mathrm{DQ} 1\end{array}$ & 52.10 & 40.60 & [39] \\
\hline
\end{tabular}




\section{Conclusions}

In this study, we tested a novel vacuum assisted in-situ gas striping recovery system for ethanol removal from a column bioreactor. Using a semi-solid process combining SBP hydrolysis and fermentation, the impact of the pressure rate, the recycling ratio and the solid concentration on the overall process was assessed. Following a statistical analysis, the recycling and vacuum ratio had the strongest impact on ethanol production. Using Pareto charts, we show that the recycling ratio is the most important variable affecting the hydrolysis step, and that the pressure ratio is the most important variable affecting the vacuum stripping step. The herein established mathematical models that describe these hydrolysis/fermentation processes can be further used for the ethanol production optimization. Additionally, these results can be utilized for the development of an integrated simultaneous fermentation and in-situ gas striping vacuum distillation process. Future trends of this research will address the scale-up for industrial bioethanol production.

Author Contributions: Conceptualization, T.R.; Methodology, D.O. and T.R.; Software, M.A. and T.R.; Validation, T.R. and R.L.; Formal analysis, M.A., D.O. and T.R.; Investigation, M.A. and D.O.; Data curation, M.A. and T.R.; Writing-original draft preparation, M.A. and T.R.; Writing-review and editing, M.A. and R.L.; Supervision, T.R. and B.Š.

Funding: This research received no external funding.

Acknowledgments: This work was supported financially by the Croatian Science Foundation under the project No. 9158 "Sustainable production of bioethanol and biochemicals from agricultural waste lignocellulosic raw materials".

Conflicts of Interest: The authors declare no conflict of interest.

\section{Abbreviations}

$\mathrm{c}_{\mathrm{G}}$
$\mathrm{c}_{\text {EtOH }}$
$\mathrm{c}_{\text {DM SBP (Hydrolysis) }}$
$\mathrm{c}_{\text {EtOH (Fermenter) }}$
$\mathrm{c}_{\text {EtOH (Condensate) }}$
$\mathrm{c}_{\text {DM SBP+YEAST }}$
$\mathrm{F}_{\mathrm{LR}}$
$\mathrm{p}$

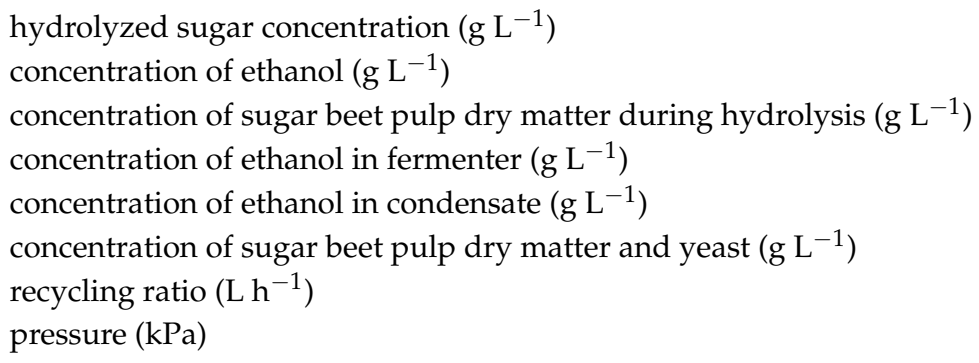

\section{References}

1. Cysewski, G.R.; Wilke, C.R. Rapid ethanol fermentations using vacuum and cell recycle. Biotechnol. Bioeng. 1997, 19, 1125-1143. [CrossRef]

2. Silva, F.L.D.H.; Rodrigues, M.I.; Maugeri, F. Dynamic modeling simulation and optimization of an extractive continuous alcoholic fermentation process. J. Chem. Technol. Biotechnol. 1999, 74, 176-182. [CrossRef]

3. Liu, H.S.; Hsu, H.W. Analysis of gas stripping during ethanol fermentation-1 in a continuous stirred tank reactor. Chem. Eng. Sci. 1990, 45, 1289-1299. [CrossRef]

4. Daugulis, A.J.; Axford, D.B.; McLellan, P.J. The economics of ethanol production by extractive fermentation. Can. J. Chem. Eng. 1991, 69, 488-497. [CrossRef]

5. Gryta, M.; Morawski, A.W.; Tomaszewske, M. Ethanol production in membrane distillation bioreactor. Catalys. Today 2000, 56, 159-165. [CrossRef]

6. Liu, Z.; Zeng, A.W. Ethanol production by strip-flash fermentation. Chem. Eng. 2008, 36, 50-53.

7. Mariano, A.P.; Mohammad, J.K.; Atala, D.I.P.; Filho, F.M.; Wolf Maciel, M.R.; Filho, R.M.; Stuart, P. Energy requirements for butanol recovery using the flash fermentation technology. Energy Fuel 2011, 25, 2347-2355. [CrossRef]

8. Qureshi, N.; Blaschek, H.P. Recovery of butanol from fermentation broth by gas stripping. Renew. Energy 2001, 22, 557-564. [CrossRef] 
9. Roychoudhury, P.K.; Ghose, T.K.; Ghosh, P.; Chotani, G.K. Vapor liquid equilibrium behavior of aqueous ethanol solution during vacuum coupled simultaneous saccharification and fermentation. Biotechnol. Bioeng. 1986, 28, 972-976. [CrossRef] [PubMed]

10. Walsh, P.K.; Liu, C.P.; Findley, M.E.; Liapis, A.I.; Siehr, D.J. Ethanol separation from water in a two-stage adsorption process. Biotechnol. Bioeng. Symp. 1983, 13, 629-647.

11. Pham, C.B.; Motoki, M.; Matsumura, M.; Kataoka, H.J. Simultaneous ethanol fermentation and stripping process coupled with rectification. Ferment. Bioeng. 1989, 68, 25-31. [CrossRef]

12. Taylor, F.; Kurantz, M.J.; Goldberg, N.; McAloon, A.J.; Craig, J.C., Jr. Dry-grind process for fuel ethanol by continuous fermentation and stripping. Biotechnol. Progr. 2000, 16, 541-547. [CrossRef] [PubMed]

13. Ezeji, T.C.; Qureshi, N.; Blaschek, H.P. Production of acetone butanol (AB) from liquefied corn starch, a commercial substrate, using Clostridium beijerinckii coupled with product recovery by gas stripping. J. Ind. Microbiol. Biotechnol. 2007, 34, 771-777. [CrossRef] [PubMed]

14. Zhang, J.; Liu, H.J.; Liu, D.H. Effect of different types of gas in gas stripping ethanol fermentation (GSEF). Chin. J. Process. Eng. 2005, 5, 349-352.

15. Márquez, M.A.; Velloso, A.A. Sistema de Fermentaçăo de Etanol (Ethanol Fermentation System). Brazilian Patent PI 0801209-1, 14 April 2008.

16. Taylor, F.; Marquez, M.A.; Johnston, D.B.; Goldberg, N.M.; Hicks, K.B. Continuous high-solids corn liquefaction and fermentation with stripping of ethanol. Bioresour. Technol. 2010, 101, 4403-4408. [CrossRef] [PubMed]

17. De Vrije, T.; Budde, M.; van der Wal, H.; Claassen, P.A.; López-Contreras, A.M. "In situ” removal of isopropanol, butanol and ethanol from fermentation broth by gas stripping. Bioresour. Technol. 2013, 137, 153-159. [CrossRef] [PubMed]

18. Chen, H.Z.; Liu, Z.H.; Dai, S.H. A novel solid state fermentation coupled with gas stripping enhancing the sweet sorghum stalk conversion performance for bioethanol. Biotechnol. Biofuels 2014, 7, 53. [CrossRef] [PubMed]

19. Sonego, J.L.S.; Lemos, D.A.; Pinto, C.E.M.; Cruz, A.J.G.; Badino, A.C. Extractive Fed-Batch Ethanol Fermentation with $\mathrm{CO}_{2}$ Stripping in a Bubble Column Bioreactor. Energy Fuels 2016, 30, 748-757. [CrossRef]

20. Jin, M.; Sarks, C.; Bals, B.D.; Posawatz, N.; Gunawan, C.; Dale, B.E.; Balan, V. Toward high solids loading process for lignocellulosic biofuel production at a low cost. Biotechnol. Bioeng. 2017, 114, 980-989. [CrossRef] [PubMed]

21. Andlar, M.; Rezić, I.; Oros, D.; Kracher, D.; Ludwig, R.; Rezić, T.; Šantek, B. Optimization of enzymatic sugar beet hydrolysis in a horizontal rotating tubular bioreactor. J. Chem. Technol. Biotechnol. 2016, 92, 623-632. [CrossRef]

22. Kracher, D.; Oros, D.; Yao, W.; Preims, M.; Rezić, I.; Haltrich, D.; Rezić, T.; Ludwig, R. Fungal secretomes enhance sugar beet pulp hydrolysis. Biotechnol. J. 2014, 9, 483-492. [CrossRef] [PubMed]

23. Rezić, T.; Oros, D.; Marković, I.; Kracher, D.; Ludwig, R.; Šantek, B. Integrated hydrolastion and fermentation of the sugar beet pulp to bioethanol. J. Microbiol. Biotechnol. 2013, 23, 1244-1252. [CrossRef] [PubMed]

24. Oros, D. Development of Sustainable Processes for Bioethanol Production. Ph.D. Thesis, Faculty of Food Technology and Biotechnology, University of Zagreb, Zagreb, Croatia, 2013.

25. Miller, G.L. Use of dinitrosalicylic acid reagent for determination of reducing sugars. Analyt. Chem. 1959, 31, 426-428. [CrossRef]

26. Phillips, C.M.; Iavarone, A.T.; Marletta, M.A. Quantitative proteomic approach for cellulose degradation by Neurospora crassa. J. Proteome Res. 2011, 10, 4177-4185. [CrossRef] [PubMed]

27. Tian, C.; Beeson, W.T.; Iavarone, A.T.; Sun, J.; Marletta, M.A.; Cate, J.H.D.; Glass, N.L. Systems analysis of plant cell wall degradation by the model filamentous fungus Neurospora crassa. Proc. Natl. Acad. Sci. USA 2009, 106, 22157-22162. [CrossRef] [PubMed]

28. Fushinobu, S. Metalloproteins: A new face for biomass breakdown. Nat. Chem. Biol. 2014, 10, 88-89. [CrossRef] [PubMed]

29. Cha, Y.-L.; An, G.H.; Yang, J.; Moon, Y.-H.; Yu, G.-D.; Ahn, J.-W. Bioethanol production from Miscanthus using thermotolerant Saccharomyces cerevisiae mbc 2 isolated from the respiration-deficient mutants. Renew. Energy 2015, 80, 259-265. [CrossRef] 
30. Kumar, S.; Dheeran, P.; Singh, S.P.; Mishra, I.M.; Adhikari, D.K. Continuous ethanol production from sugarcane bagasse hydrolysate at high temperature with cell recycle and in-situ recovery of ethanol. Chem. Eng. Sci. 2015, 138, 524-530. [CrossRef]

31. Lopez-Linares, J.C.; Romero, I.; Cara, C.; Ruiz, E.; Castro, E.; Moya, M. Experimental study on ethanol production from hydrothermal pretreated rapeseed straw by simultaneous saccharification and fermentation. J. Chem. Technol. Biotechnol. 2014, 89, 104-110. [CrossRef]

32. Gonçalves, F.A.; Ruiz, H.A.; Nogueira, C.C.; Santos, E.S.; Teixeira, J.A.; Macedo, G.R. Comparison of delignified coconuts waste and cactus for fuel-ethanol production by the simultaneous and semi-simultaneous saccharification and fermentation strategies. Fuel 2014, 131, 66-76. [CrossRef]

33. Narra, M.; James, P.; Balasubramanian, V. Simultaneous saccharification and fermentation of delignified lignocellulosic biomass at high solid loadings by a newly isolated thermotolerant Kluyveromyces sp. for ethanol production. Bioresour. Technol. 2015, 179, 331-338. [CrossRef] [PubMed]

34. Kumagai, A.; Kawamura, S.; Lee, S.-H.; Endo, T.; Rodriguez, M., Jr.; Mielenz, J.R. Simultaneous saccharification and fermentation and a consolidated bioprocessing for Hinoki cypress and Eucalyptus after fibrillation by steam and subsequent wet-disk milling. Bioresour. Technol. 2014, 162, 89-95. [CrossRef] [PubMed]

35. Sonego, J.L.S.; Lemos, D.A.; Rodriguez, G.Y.; Cruz, A.J.G.; Badino, A.C. Extractive Batch Fermentation with $\mathrm{CO}_{2}$ Stripping for Ethanol Production in a Bubble Column Bioreactor: Experimental and Modeling. Energy Fuels 2014, 28, 7552-7559. [CrossRef]

36. Ahmed, I.N.; Sutanto, S.; Huynh, L.H.; Ismadji, S.; Ju, Y.-H. Subcritical water and dilute acid pretreatments for bioethanol production from Melaleuca leucadendron shedding bark. Biochem. Eng. J. 2013, 78, 44-52. [CrossRef]

37. Xue, C.; Zhao, J.; Liu, F.; Lu, C.; Yang, S.-T.; Bai, F.-W. Two-stage in situ gas stripping for enhanced butanol fermentation and energy-saving product recovery. Bioresour. Technol. 2013, 135, 396-402. [CrossRef] [PubMed]

38. Manzanares, P.; Negro, M.J.; Oliva, J.M.; S’aez, F.; Ballesteros, I.; Ballesteros, M.J. Different process configurations for bioethanol production from pretreated olive pruning biomass. J. Chem. Technol. Biotechnol. 2011, 86, 881-887. [CrossRef]

39. Zhang, J.; Chu, D.; Huang, J.; Yu, Z.; Dai, G.; Bao, J. Simultaneous Saccharification and Ethanol Fermentation at High Corn Stover Solids Loading in a Helical Stirring Bioreactor. Biotechnol. Bioeng. 2010, 105, 718-728. [CrossRef] [PubMed] 